\title{
Phytoplankton community dynamic detection from the chlorophyll-specific absorption coefficient in productive inland waters
}

Detecção da dinâmica de comunidade fitoplanctônica a partir do coeficiente de absorção específico da clorofila em águas interiores produtivas

Fernanda Sayuri Yoshino Watanabe ${ }^{1 *}$, Enner Herenio de Alcântara²,

Thanan Walesza Pequeno Rodrigues ${ }^{1}$, Nariane Marselhe Ribeiro Bernardo ${ }^{1}$,

Luiz Henrique da Silva Rotta ${ }^{1}$ and Nilton Nobuhiro Imai ${ }^{1}$

${ }^{1}$ Departamento de Cartografia, Faculdade de Ciências e Tecnologia - FCT, Universidade Estadual Paulista - UNESP, Rua Roberto Simonsen, 305, CEP 19060-900, Presidente Prudente, SP, Brazil ${ }^{2}$ Departamento de Engenharia Ambiental, Instituto de Ciências e Tecnologia - ICT, Universidade Estadual Paulista - UNESP, Rodovia Presidente Dutra, Km 137.8, CEP 12247-004, São José dos Campos, SP, Brazil

*e-mail: fernandasyw@gmail.com

Cite as: Watanabe, F.S.Y. et al. Phytoplankton community dynamic detection from the chlorophyll-specific absorption coefficient in productive inland waters. Acta Limnologica Brasiliensia, 2017, vol. 29, e13.

Abstract: Aim: In this research, we investigated the spectral variability of the specific phytoplankton absorption coefficient, $a_{\varphi^{*}}^{*}$, measured in a tropical meso-to-hypertrophic reservoir, aiming to find spectral features associated with the chlorophyll- $a(\operatorname{chl} l a)$ and other accessory pigments present in different phytoplankton species. Methods: To accomplish this research, two fieldworks were carried out in different seasons in order to report a high bio-optical variation. Phytoplankton absorption coefficient, $a_{\varphi}$, and chla concentration were measured in laboratory to estimate $a_{\varphi}^{*}$. Results: The outcomes have indicated that there is a remarkable phytoplankton community dynamic as spatially as seasonally. Chl $a$ absorption features were well-defined at $440 \mathrm{~nm}$ and $675 \mathrm{~nm}$. Conclusions: All the $a_{\varphi}^{*}$ spectra exhibited the absorption peak around $630 \mathrm{~nm}$ associated with phycocyanin pigment present in cyanobacteria. Some spectra have shown a peak at about $460 \mathrm{~nm}$, which is related to chlorophyll $b$ and chlorophyll $c$ (chl $b$ and $\mathrm{chl} c$, respectively) found in different phytoplankton species. In turn, absorption features of carotenoids around $490 \mathrm{~nm}$ also were identified, however, well defined just in curves measured in austral autumn. Such spectral features are found in phytoplankton groups already identified in the study area such as Chlorophyceae, Bacillariophyceae, Cyanophyceae, Conjugatophyceae, Chrysophyceae, among others. We expect that the results are useful in researches about remote sensing of phytoplankton and eutrophication in reservoirs.

Keywords: inherent optical properties; inland waters; spectral features; algal bloom.

Resumo: Objetivo: Nesta pesquisa, foi investigada a variabilidade espectral do coeficiente de absorção específico do fitoplâncton, $a_{\varphi}^{*}$, medido em um reservatório meso-a-hipertrófico tropical, com o objetivo de encontrar feiçóes espectrais associadas à clorofila- $a$ (chla) e pigmentos acessórios de diferentes espécies de fitoplâncton. Métodos: Para realizar este trabalho, dois levantamentos de campo foram realizados em diferentes estaçôes a fim de registrar a alta variação bio-ótica. O coeficiente 
de absorção do fitoplâncton, $a_{\text {e }}$, e a concentraçáo de chla foram medidos em laboratório para estimar $a_{\varphi}^{*}$. Resultados: $\mathrm{O}$ resultado indicou uma alta variação de comunidades de fitoplâncton tanto sazonalmente quanto espacialmente. As feiçóes de absorção da chla estavam bem acentuadas em $440 \mathrm{~nm}$ e $675 \mathrm{~nm}$. Conclusóes: Todas as curvas de $a_{\varphi}^{*}$ exibiram um pico de absorção ao redor de $630 \mathrm{~nm}$, associado ao pigmento ficocianina presente em cianobactérias. Alguns espectros apresentaram picos em torno de $460 \mathrm{~nm}$, que está relacionado à presença de clorofila- $b$ e clorofila- $c$ (chlb e chl $c$, respectivamente), encontrados em algumas espécies de fitoplâncton. Por sua vez, as feiçóes de absorção por carotenóides, por volta de $490 \mathrm{~nm}$, também foram identificadas, entretanto, estavam bem definidas apenas em curvas adquiridas no outono. Essas feiçôes espectrais são encontradas em grupos de fitoplânctons já identificados na área de estudo, como Chlorophyceae, Bacillariophyceae, Cyanophyceae, Conjugatophyceae, Chrysophyceae, entre outros. Espera-se que os resultados obtidos nesse estudo possam ser úteis em estudos sobre sensoriamento remoto de águas interiores e eutrofização de reservatórios.

Palavras-chave: propriedades ópticas inerentes; águas interiores; feiçôes espectrais de pigmentos; floração de algas.

\section{Introduction}

The natural waters are composed of particulate and dissolved matters, which model the water color. Such materials present in water column are called optically significant constituents (OSCs) (Morel \& Prieur, 1977). The sort of OSCs and their concentrations are responsible for changing the optical inherent properties (IOPs) of the water, i.e., the absorption and scattering coefficients ( $a$ and $b$, respectively) (Mobley, 1994). Knowledge about the IOPs alternations is essential for the remote sensing of the water color, since $a$ and $b$ are the main factors responsible for modeling the reflectance (Gordon et al., 1988). In addition, the attenuation properties are essential to understand the underwater light climate (Campbell et al., 2011; Riddick et al., 2015), and how they influence important processes in water column such as photosynthesis, biodiversity, among others.

The $a$ may be considered as the sum of the absorption coefficients of water $\left(a_{\mathrm{w}}\right)$, phytoplankton pigments $\left(a_{\varphi}\right)$, colored dissolved organic matter $\left(a_{\mathrm{CDOM}}\right)$ and non-algal particles $\left(a_{\mathrm{NAP}}\right)$. The $a_{\mathrm{CDOM}}$ and $a_{\mathrm{NAP}}$ exhibit an exponential pattern, varying with the spectral slope, whereas $a_{\varphi}$ does not present a pattern, with spectral features such as peaks and shoulders, which vary based on pigment content present in phytoplankton assemblages (Mobley, 1994; Babin et al., 2003; Campbell et al., 2011). Besides the sort of pigments, $a_{\varphi}$ is strongly dependent on their concentrations, hence, the phytoplankton-specific absorption coefficient $\left(a_{\varphi}^{*}\right)$ is usually used to investigate the pigment content (Mobley, 1994) and compare it with other aquatic systems (Campbell et al., 2011).

Due to spectrally selective absorption of the chla and other accessory pigments (Richardson, 1996), it is possible to identify their absorption features from $a_{\varphi}^{*}$ curves (Le et al., 2009). The accessory pigment content and concentration directly depend upon phytoplankton species. Ruiz-Verdú et al. (2008) indicated spectral difference in reflectance and absorbance curves associated with phytoplankton groups (cyanobacteria, chlorophyta and diatom). Phytoplankton specie detection is important due to existence of harmful algae such as cyanobacteria (Cullen et al., 1997; Stumpf et al., 2016). Due to its spectral nature and public health importance, there are many studies attempting to identify the cyanobacteria presence in water bodies based on quantification of the phycocyanin pigment using remote sensing data (Schalles \& Yacobi, 2000; Simis et al., 2005; Ruiz-Verdú et al., 2008; Mishra \& Mishra, 2012).

Besides the phytoplankton assemblage dynamic, the $a_{\varphi}^{*}$ variability may be affected by package effect, which is associated with the pigment content, cell size and increase of phytoplankton biomass (Bricaud et al., 1995; Ciotti et al., 2002; Babin et al., 2003). The package effect or pigment packaging occurs when the increase of the phytoplankton biomass leads to shading of their cells. This cause flattening $a_{\varphi}^{*}$ curve because the maximum pigment absorption features do not increase proportionally with the elevation of their concentration (Duyens, 1956). Such effect is related to algal cell size and intracellular pigment concentration, inducing variations in magnitude of the $a_{\varphi}^{*}$ spectrum (Bricaud \& Stramski, 1990; Bricaud et al., 1995). According to Paavel et al. (2016), environmental factors such as light availability, temperature and nutrient supply are responsible for variations in cell size and pigment content.

Thus, this research assumed that it is possible to detect phytoplankton assemblage dynamic taking into account the spectral alterations that 
cause in $a_{\varphi}^{*}$ curves. In this context, this research was carried out aiming to detect the phytoplankton group changes through alterations in $a_{\varphi}^{*}$ spectra in inland waters. The specific objectives are to: (1) identify spatial and seasonal differences in $a_{\varphi}^{*}$ spectra and (2) relate the absorption features of the spectrally identified pigment with the phytoplankton groups historically found in the study area. We expect that the findings in this research may be useful in other studies aimed at identifying phytoplankton groups from remote sensing imagery and eutrophication.

\section{Data and Methods}

\subsection{Study area and sampling}

The study area was the Barra Bonita hydroelectric reservoir (BBHR), which lies on the middle course of Tietê River, São Paulo State, Brazil (Figure 1). The BBHR is the first one of a cascade system composed of six reservoirs (Barra Bonita, Bariri, Ibitinga, Promissão, Nova Avanhandava and Três Irmãos - upstream to downstream). The reservoir is a eutrophic aquatic environment, classified by Watanabe et al. (2015) as meso-to-hypertrophic, because receives a high load of pollutants (Smith et al., 2014), coming from big urban centers such as São Paulo and Piracicaba regions. In addition, nonpoint source pollution also is responsible for the eutrophication. The high trophic level turns BBHR into a emitter of greenhouse gases such as methane $\left(\mathrm{CH}_{4}\right)$, carbon dioxide $\left(\mathrm{CO}_{2}\right)$ and nitrous oxide $\left(\mathrm{NO}_{2}\right)$ (Abe et al., 2003).

Two fieldworks were carried out in the BBHR, on May 5-9 (post rainy season) and October 13-16, 2014 (post dry season). The collection of water samples were done in 20 sampling stations randomly distributed along the reservoir by using method proposed by Rodrigues et al. (2016) (Fig. 1b). Water samples were stored in sterile plastic bottles of $5 \mathrm{~L}$, cooled and in dark until filtration in the same day. Other optical parameters of water quality such as turbidity and Secchi disk depth (SDD) also were measured in situ.

\subsection{Chla and total suspended material (TSM) concentrations}

The filtration of water samples was done at the same day of collection in order to avoid the degradation of the OSCs. To determine the chla concentration, water samples were filtered through Whatman GF/F glass fiber filter (GE Healthcare, Little Chalfont, UK), with $0.7 \mu \mathrm{m}$ porosity and $0.47 \mathrm{~mm}$ diameter. After filtration, the filters were frozen and stored in dark to avoid degradation by heat and light. Chla extraction was done by using method proposed by Golterman (1975), which uses $90 \%$ acetone solution. Chla estimation was done from measurements of absorbance acquired at $663 \mathrm{~nm}$ and $750 \mathrm{~nm}$, using a FEMTO spectrophotometer (FEMTO, São Paulo, Brazil). In order to remove the influence of phaeophytin (degradation product of the chla), chla samples were acidified from a $0.1 \mathrm{~N} \mathrm{HCl}$ solution and read again.

In turn, to determine the TSM concentration we adopted the protocol defined by APHA (2005). Before filtration, the Whatman GF/F filters were prepared, burning them in muffle furnace and weighting in order to obtain the initial mass of the filters. After filtration, the filters with retained material were frozen and stored in the dark until laboratorial analysis. Filtered samples were dried
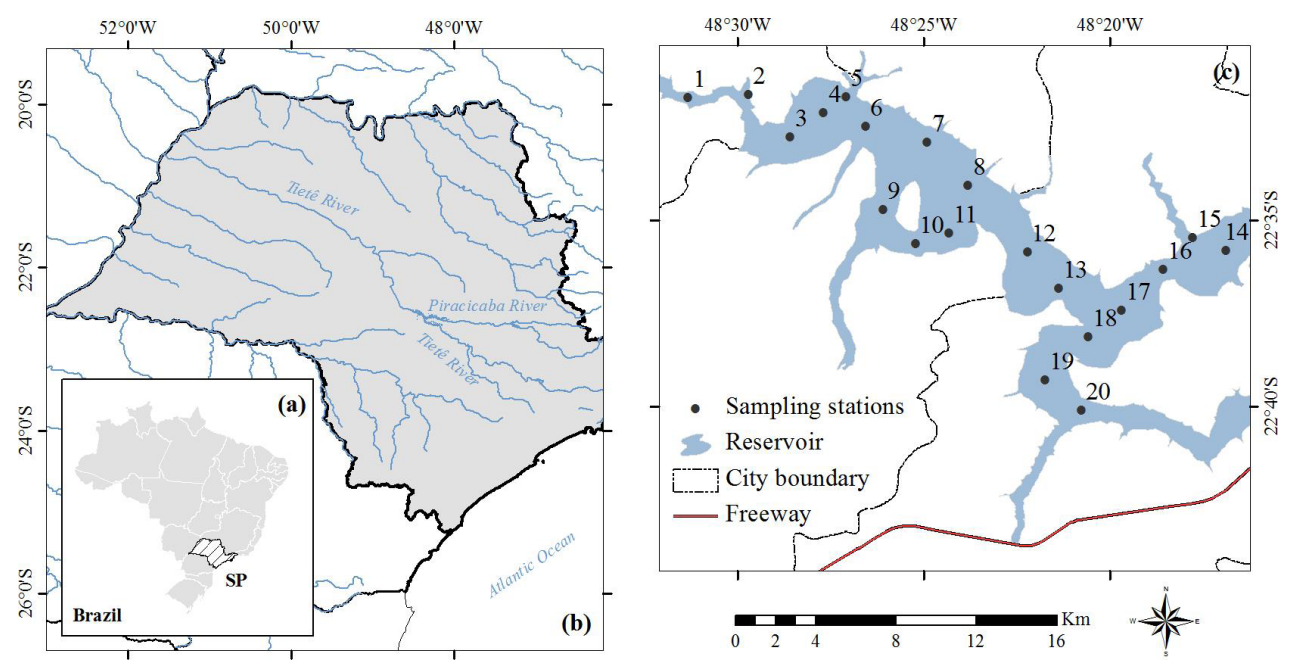

Figure 1. Barra Bonita hydroelectric reservoir and its location in Brazil and São Paulo State (highlighted) (a); cascade system in Tietê River (b); and sampling stations (c). 
in an oven over $110^{\circ} \mathrm{C}$ for $12 \mathrm{~h}$ and, then, were desiccated and weighted to obtain the TSM mass. Dividing the TSM mass by the filtered water volume it is determined the TSM concentration.

\subsection{Specific absorption coefficient of phytoplankton pigment, $a_{\varphi}^{*}$}

To determine $a_{\varphi}^{*}$ it is need to estimate the absorption coefficient of total particles $\left(a_{\mathrm{p}}\right), a_{\mathrm{NAP}}$ and $a_{0}$ by using 'Transmittance-Reflectance' method (Tassan \& Ferrari, 1995, 1998, 2002). Water samples were filtered through Whatman GF/F filters, frozen and stored in dark sterile jars to avoid the degradation of the material. Measurements of transmittance and reflectance were taken by using a UV-2600 spectrophotometer (Shimadzu, Kyoto, Japan), with double beam mode and integrating sphere. The spectral range setup was from $280-800 \mathrm{~nm}$, with spectral resolution of $1 \mathrm{~nm}$. A clear filter was used as blank reference to correct the multiple scattering effects caused by filter itself (Cleveland \& Weidemann, 1993). The optical density of total particles $\left(O D_{\mathrm{p}}\right)$ was empirically estimated based on the transmittance and reflectance measurements. From the phytoplankton pigment oxidation using a $10 \% \mathrm{NaClO}$ solution, the optical density of NAP $\left(O D_{\mathrm{NAP}}\right)$ was obtained. Then, $a_{\mathrm{p}}$ and $a_{\mathrm{NAP}}$ were estimated from Equation 1 .

$\mathrm{a}_{\mathrm{p}, \mathrm{NAP}}(\lambda)=\frac{2.3 \mathrm{OD}_{\mathrm{p}, \mathrm{NAP}}(\lambda)}{\mathrm{X}}$

where $X$ is the ratio of the filtered volume to filter clearance area. Subtracting $a_{\mathrm{NAP}}$ of $a_{\mathrm{p}}$ is obtained $a_{\varphi}$ and dividing it by pigment concentration is derived $a_{\varphi}^{*}$. Here, we divided $a_{\varphi}$ by chla concentration.

\section{Results}

\subsection{Water quality parameters}

Table 1 displays a descriptive statistic of optical water quality parameters (chla, TSM, turbidity and SDD) gathered out in two field surveys, showing a high seasonal variability. There was a remarkable increase between measurements of May and October. In May, chla concentration ranged from $17.7 \mathrm{mg} \mathrm{m}^{-3}$ to $279.9 \mathrm{mg} \mathrm{m}^{-3}$, while, in October, the range was from $263.2 \mathrm{mg} \mathrm{m}^{-3}$ to $797.8 \mathrm{mg} \mathrm{m}^{-3}$. The increase of the trophic level was so significant that the maximum value reported in May was approximately the minimum value of October. TSM concentration followed the increase of chl $a$, with a range of $3.6 \mathrm{~g} \mathrm{~m}^{-3}$ to $16.3 \mathrm{~g} \mathrm{~m}^{-3}$, in May, and $10.8 \mathrm{~g} \mathrm{~m}^{-3}$ to $44.0 \mathrm{~g} \mathrm{~m}^{-3}$, in October. In addition, TSM is mainly composed of organic portion, likely associated with the phytoplankton biomass (Watanabe et al., 2016). Consequently, the Chla:TSM ratio also increased, indicating a higher contribution of phytoplankton biomass over TSM.

The increase of OSC concentrations reflected in the $a_{\varphi}(440)$ values from May to October. The high influence of the phytoplankton may be verified in Figure 2, which shows the contribution of each OSC for $a$, taking into account the wavelengths at 440, 620 and $675 \mathrm{~nm}$. Analyzing the ternary plots, the phytoplankton dominance is notable in the aquatic system. Overall, the $a_{\varphi}$ showed high contribution in both fieldworks, but especially in October. In May, the $a_{\mathrm{CDOM}}$ exhibited expressible contribution at $440 \mathrm{~nm}$, with maximum value of approximately 0.5 . On the other hand, the $a_{\varphi}$ was predominant at the three analyzed wavelengths, mainly at $675 \mathrm{~nm}$ ranging from 0.86 to 0.98 .

Table 1. Descriptive statistic of chl $a$ in $\mathrm{mg} \mathrm{m}^{-3}$, TSM in $\mathrm{g} \mathrm{m}^{-3}$, Chl $a: T S M$ in $\mathrm{mg} \mathrm{g}^{-1}$, SDD in $\mathrm{m}$, turbidity in NTU and $a_{\varphi}$ in $\mathrm{m}^{-1}$.

\begin{tabular}{ccccccc}
\hline Period & Parameters & Minimum & Maximum & Average & $\begin{array}{c}\text { Standard } \\
\text { Deviation }\end{array}$ & $\begin{array}{c}\text { Coefficient of } \\
\text { Variation, \% }\end{array}$ \\
\hline May & Chla & 17.7 & 279.9 & 120.4 & 70.3 & 58.4 \\
& TSM & 3.6 & 16.3 & 7.2 & 3.3 & 45.8 \\
& Chla:TSM & 4.0 & 27.8 & 16.7 & 7.1 & 42.2 \\
& SDD & 0.8 & 2.3 & 1.5 & 0.4 & 26.7 \\
& Turbidity & 1.7 & 12.5 & 5.2 & 2.4 & 46.2 \\
& $a_{\varphi}(440)$ & 0.3 & 2.6 & 1.2 & 0.6 & 52.1 \\
October & Chla & 263.2 & 797.8 & 428.7 & 154.5 & 36.0 \\
& TSM & 10.8 & 44.0 & 22.0 & 7.0 & 31.8 \\
& Chla:TSM & 12.9 & 35.0 & 20.1 & 6.2 & 30.9 \\
& SDD & 0.4 & 0.8 & 0.6 & 0.1 & 16.6 \\
& Turbidity & 11.6 & 33.2 & 18.6 & 5.3 & 28.5 \\
& $a_{\varphi}(440)$ & 2.8 & 10.9 & 5.0 & 2.0 & 40.3 \\
\hline
\end{tabular}


As expected, the elevation of OSC influenced the turbidity values, from 5.2 NTU (May) to 18.6 NTU (October), whereas, on the contrary, there was a reduction of the SDD.

\subsection{Dynamic of $a_{\varphi}^{*}$}

The high variation of chla concentration showed the elevation of the trophic level from May to October, whilst $a_{\varphi}^{*}$ spectra indicated the variability of phytoplankton species and mixture of groups. Figure 3 displays $a_{\varphi}^{*}$ spectra recorded in May and October, with a great spectral variability. The $a_{i}^{*}$ spectra exhibited different peaks associated with absorption properties of chl $a$ and other accessory pigments (Lohrenz et al., 2003; Le et al., 2009).

The different spectral features observed in $a_{\varphi}^{*}$ spectra indicated the variability of phytoplankton species. As expected, absorption peaks at about $440 \mathrm{~nm}$ and $675 \mathrm{~nm}$ associated with chl $a$ were identified in all the curves and more highlighted when compared with other spectral features. Another peak found in all the spectra was at about $630 \mathrm{~nm}$, related to phycocyanin pigment exclusively present in cyanobacteria (Simis et al., 2005). The magnitude of this peak varied considerably, pointing to variations in the intracellular pigment content and phytoplankton species mixing.

Couple of months exhibited a peak at approximately $460 \mathrm{~nm}$ associated with presence of chl $b$ and chlc (Lohrenz et al., 2003). Chl $b$ is usually found in green algae such as Chlorophyceae, Conjugaophyceae and Euglenophyta, whilst chlc is present in brown algae (Crysophyceae) and dinoflagellates (Dinophyceae) (Richardson, 1996). All those groups have already identified in the BBHR (Calijuri et al., 2002; Matsumura-Tundisi \& Tundisi, 2005; Dellamano-Oliveira et al., 2008). Carotenoids features were found at
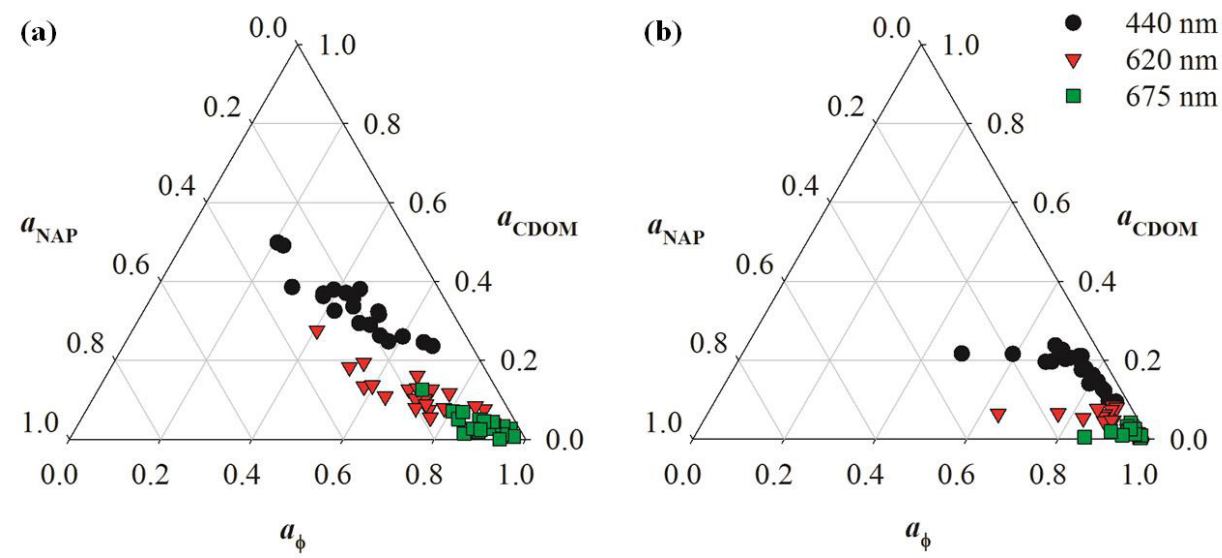

Figure 2. Ternary plots show the contribution of each optically significant constituent for $a$ at 440,620 and $665 \mathrm{~nm}$ collected in May (a) and October (b).
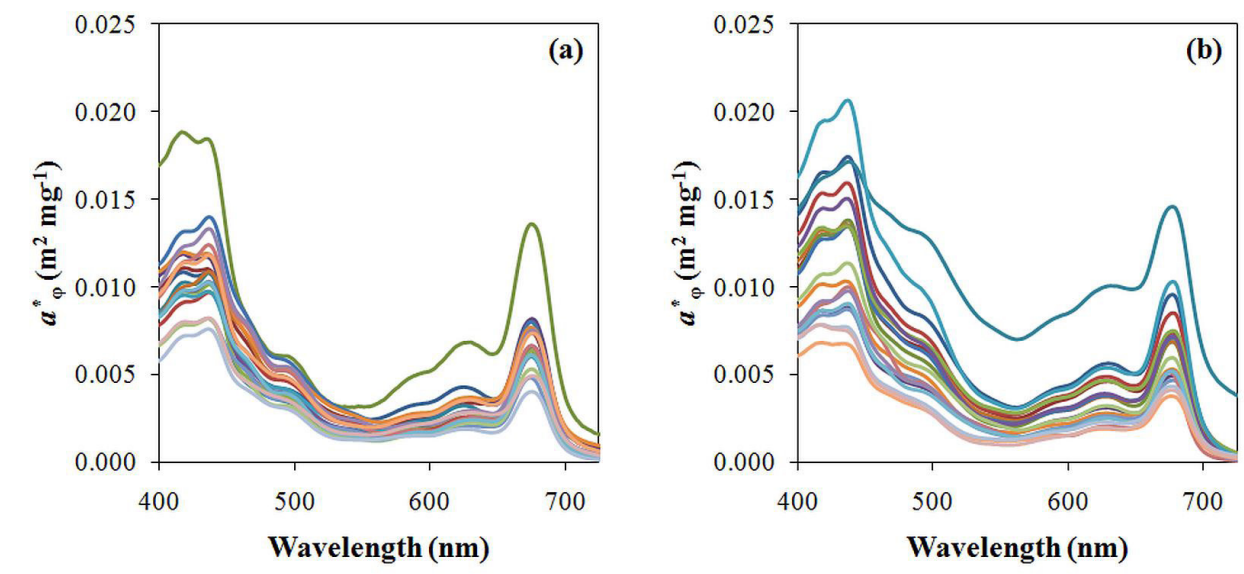

Figure 3. $a^{*}{ }_{\varphi}$ spectra measured in May (a) and October (b) 2014. 
490 and $540 \mathrm{~nm}$ (Lohrenz et al., 2003). Particularly, the fucoxantin pigment is present in diatoms (Bacilloriophyceae), dominant specie in rainy season in the BBHR (Dellamano-Oliveira et al., 2008; Tundisi et al., 2010).

Lohrenz et al. (2003) showed that the ratio $a_{\varphi}(440): a_{\varphi}(675)$ has a direct relationship with the accessory pigment portion in relation to chla. In May, such ratio ranged from 1.30 to 1.83 , with an average value of 1.58 , whereas, in October, the variation was higher ranging from 1.17 to 2.07 , with an average value of 1.83 . Besides presenting a temporal variation, $a_{\phi}(440): a_{\phi}(675)$ showed an important spatial variability. Overall, in May, the lowest ratios were reported in sampling stations close to the dam (1 to 4$)$. On the other hand, in October, the highest ratios were obtained in these same stations, indicating there was a change in the phytoplankton community and/or predominance for another specie.

In order to detect spectral differences in the curves, we normalized $a_{\varphi}^{*}$ spectra in relation to $a_{\varphi}^{*}(440)\left[a_{\varphi}^{*}: a_{\varphi}^{*}(440)\right]$. The wavelength at $440 \mathrm{~nm}$ was chosen due to maximum absorption of chla. The normalization highlights the gradient between minimum and maximum absorption features. Figure 4 displays normalized representative spectra of the $a_{\varphi}^{*}$ variability taken in four sampling stations (3, 5, 14 and 20). Such stations were chosen because exhibited significant spatial-temporal changes in their $a_{\varphi}^{*}$ spectra. Spectral differences are mainly determined by composition of accessory pigments (Lohrenz et al., 2003; Le et al., 2009).

The station 3 showed well-defined features of chla $(410 \mathrm{~nm}, 440 \mathrm{~nm}$ and $675 \mathrm{~nm})$, phycocyanin $(630 \mathrm{~nm})$ and carotenoids (490 nm) (Figure 4a). The main difference detected between the curves collected in May and October was the increase of features associated with accessory pigments in the blue spectrum. The May curve clearly exhibited a shoulder between $410 \mathrm{~nm}$ and $440 \mathrm{~nm}$, stimulated by chla, and it was noticed more discrete features related to accessory pigments. On the other hand, the October curve exhibited a smoother pattern, with higher absorption by carotenoids and lower by phycocyanin. This finding is an indicative of higher dominance by diatoms than cyanobacteria in October, and, the opposite in May. Therefore, it is possible to associate this result with an exchange of predominant phytoplankton group from one season to another.

The spectra of station 5 were those that exhibited the highest differences between both fieldworks (Figure 4b). The curve collected in October has a flattening and a higher magnitude in the spectral region of the green light. In addition, a slight peak at $410 \mathrm{~nm}$ was detected in the October curve, although $a_{\varphi}^{*}$ value was quite elevated at that wavelength. The common characteristics of the May and October curves were the well-defined
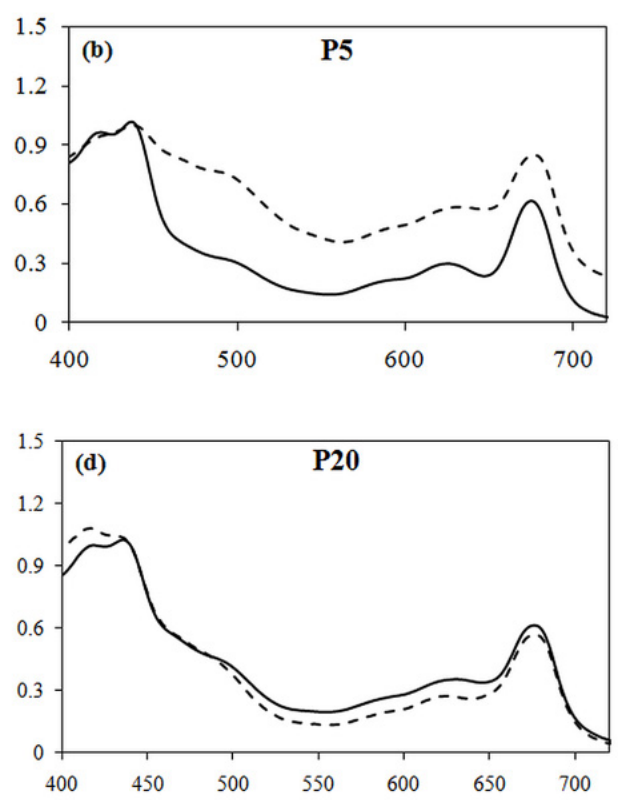

Wavelength (nm)

Figure 4. Normalized $a_{\varphi}^{*}$ spectra for $440 \mathrm{~nm}$ collected at sampling stations: 3 (a), 5 (b), 14 (c) and 20 (d). 
chl $a$ peaks and none feature associated with chl $b$ and chlc. Even though, similarly to other curves, those measured in station 5 presented peaks of carotenoids and phycocyanin. As observed in station 3, the diatoms seem to be the predominant specie in October.

Regarding the station 14, the $a_{\varphi}^{*}$ curves measured in May and October seem quite similar, nevertheless, they presented small difference in the spectral region of blue light, due to accessory pigment composition (Figure 4c). Similarity in the spectra collected in station 14 indicates there was few changes in the phytoplankton community. In May, chl $b$ and chlc peaks were detected, creating steps along the blue spectrum, while, in October, such features were not visible. This pattern of curves is similar to other measurements collected in the Piracicaba River. A common characteristic in both curves, $a_{\varphi}^{*}$ was lower at $410 \mathrm{~nm}$ than at $440 \mathrm{~nm}$, similar to station 5 measured in October. The maximum chla absorption is at approximately $440 \mathrm{~nm}$, however, when the maximum peak is shifted towards shorter wavelengths, probably there is high concentration of phaeopigments, associated with phytoplankton degradation (Bricaud et al., 1995; Le et al., 2009).

The $a_{\varphi}^{*}$ spectra measured in Tietê River before confluence with Piracicaba River are similar, in which the station 20 is an example (Figure 4d). Particularly, in May, this pattern of curve was the most common in both fieldworks, with $a_{\varphi}^{*}$ higher at $440 \mathrm{~nm}$ than $410 \mathrm{~nm}$ and features smoother for the entire spectrum, in other words, the accessory pigments features were less highlighted. On the other hand, in October, the spectrum exhibited a higher absorption at $410 \mathrm{~nm}$ compared to $440 \mathrm{~nm}$. For this month, Alcântara et al. (2016a) reported that the Tietê River section before confluence had the highest dissolved organic matter concentrations and, consequently, $a_{\mathrm{CDOM}}$. Thus, the bio-optical status of this section may have led to a different phytoplankton deployment in relation to the rest of the reservoir (Watanabe et al., 2016).

\section{Discussion}

The BBHR showed a high $a_{\varphi}^{*}$ variability as seasonal as spatial, due to alterations in phytoplankton assemblages. Those changes were identified in the $a_{\varphi}^{*}$ curves, due to content and sort of accessory pigments present in each phytoplankton specie. Further, the variability of $a^{*}{ }_{0}$ may also be associated with the package effect (Bricaud \& Stramski, 1990; Bricaud et al., 1995). Alcântara et al. (2016b) showed that the $a_{\varphi}^{*}$ was strongly affected by pigment packaging in the BBHR.

The seasonal alterations observed are an indicative of phytoplankton community exchange. Overall, the $a^{*}$ measurements were more homogenous in May than in October, however, the May curves exhibited more spectral features related to accessory pigments. Despite this, it does not mean that there was no diversity of phytoplankton species, but that a predominant specie may be masking spectral features of other species in lower amount. The weather showed an important role over phytoplankton community growth. According to Dellamano-Oliveira et al. (2008), diatoms are predominant in wet seasons, while, cyanobacteria dominate in dry season. This variation was detected in $a_{\varphi}^{*}$ spectra displayed in this research, in which features associated with cyanobacteria were more highlighted in May, whilst diatom peaks were more well-defined in October.

Calijuri \& Santos (1996) showed that phytoplankton communities are very dynamic, changing from one day to another. Tundisi et al. (2010) showed that phytoplankton assemblage changes are strongly sensible to cold fronts. Cold front incursion enhances the mixing process in winter by destabilizing the water column and the phytoplankton horizontal distribution is strongly related to the water column stability (Curtarelli et al., 2015). Despite that, a combination of different spectral features was observed in practically all the $a_{\varphi}^{*}$ curves, indicating a phytoplankton group mixing. According to Calijuri \& Santos (1996), although cyanobacteria were the dominant specie in the winter, the diatoms were predominant in terms of phytoplankton biomass.

The changes also occurred spatially, being that the most significant modifications could be observed in lacustrine zone close to the dam. In this section, the phytoplankton assemblage exchange is strongly affected by thermal stratification and water column mixing processes (Dellamano-Oliveira et al., 2008; Tundisi et al., 2010). Station 5 is a good example in showing as the reservoir hydrodynamic may strongly influence the phytoplankton communities. The $a^{*}$ spectra were more homogenous in transitional and riverine zones such as stations 14 and 20, respectively. In special, riverine zone has a higher current speed, trending to propitiate the deployment of different phytoplankton species compared with lentic regions.

In terms of magnitude, $a_{\varphi}^{*}(440)$ spectra were consistent compared to other aquatic systems. Campbell et al. (2011) recorded an average 
$a^{*}{ }_{(4}(440)$ slightly higher than $0.5 \mathrm{~m}^{2} \mathrm{mg}^{-1}$ for turbid reservoirs in Australia. An $a_{\varphi}^{*}(440)$ value of $0.5 \mathrm{~m}^{2} \mathrm{mg}^{-1}$ is relatively high compared with the values registered in the BBHR. More similar values to BBHR were reported in Lake Taihu (Le et al., 2009), with $a_{\varphi}^{*}(440)$ ranging from 0.016 to $0.181 \mathrm{~m}^{2} \mathrm{mg}^{-1}$. Lower $a_{\varphi}^{*}(440)$ values were reported in ocean waters (Bricaud et al., 1995), with a maximum $a_{\varphi}^{*}(440)$ value around $0.06 \mathrm{~m}^{2} \mathrm{mg}^{-1}$.

Besides the magnitude difference, $a_{\varphi}^{*}(440)$ measured for ocean waters may present different spectral shape, associated with the accessory pigment not found in phytoplankton from freshwater. Bricaud et al. (1995) reported $a_{\varphi}^{*}(440)$ spectra with an shoulder around $550 \mathrm{~nm}$, related to phycoerythrin. Similarly to phycocyanin, the phycoerythrin also is a biliprotein, however, it is just found in marine algae. Campbell et al. (2011) also reported $a_{\varphi}^{*}$ spectra with a well-defined peak around $490 \mathrm{~nm}$, which created a valley between 440 and $490 \mathrm{~nm}$. In turn, among curves obtained by Le et al. (2009), some spectra were well seemed with those measured in the BBHR. On the other hand, Le et al. (2009) registered strong spectral features of phaeopigments, with maximum peak shifted towards shorter wavelengths. In addition, absorption of accessory pigments is further remarkable, creating shoulders from 450 to $500 \mathrm{~nm}$.

\section{Conclusion}

The results of this study showed that is possible to identify phytoplankton groups from the $a_{\varphi}^{*}$ curves and, consequently, changes of phytoplankton assemblage. The identification was possible mainly due to absorption by accessory pigments, which allows distinguishing algae groups. The BBHR exhibited a great $a_{\varphi}^{*}$ variability, with strong spatial and temporal relationship. We have identified different spectral features related to accessory pigments such as $\mathrm{chl} b, \mathrm{chl} c$, carotenoids and phycocyanin, indicating a phytoplankton assemblage mixing. In spite of the variations, the peak at $630 \mathrm{~nm}$ was found in all the $a_{\varphi}^{*}$ curves, which indicates the presence of cyanobacteria in the entire reservoir and in both seasons (dry and wet). Cyanobacteria produce toxins, which may cause health problems. Therefore, the harmful algal bloom monitoring is important to manage the multiple use of the reservoir such as water supply, fishing and recreation. The reservoir zonation (lake, transition and river zones) also exhibited a strong influence over $a^{*}$. The particular hydrodynamic characteristics at each zone led to preferential deployment of certain species in relation to others. Consequently, this diversity may be detected in the $a_{\varphi}^{*}$ spectra.

\section{Acknowledgements}

The authors thank to Fundação de Amparo à Pesquisa do Estado de São Paulo - FAPESP (Processos N. 2012/19821-1, 2013/09045-7, 2015/18525-8 e 2015/21586-9) and Conselho Nacional de Desenvolvimento Científico e Tecnológico - CNPq (Processos N. 400881/2013-6, 482605/2013-8 e 472131/2012-5) for financial support. They also thank to Programa de Pós-Graduação em Ciências Cartográficas (FCT/UNESP) and Coordenação de Aperfeiçoamento de Pessoal de Nível Superior (CAPES/Brazil) for doctoral scholarship, and Professor Edivaldo D. Velini and the staff from Laboratory of Weed, at FCA/UNESP for allowing the use their laboratory facilities.

\section{References}

ABE, D.S., MATSUMURA-TUNDISI, T., ROCHA, O. and TUNDISI, J.G. Denitrification and bacterial community structure in the cascade of six reservoirs on a tropical river in Brazil. Hydrobiologia, 2003, 504(1-3), 67-76. http://dx.doi.org/10.1023/ B:HYDR.0000008509.47900.fc.

ALCÂNTARA, E., BERNARDO, N., WATANABE, F., RODRIGUES, T., ROTTA, L., CARMO, A., SHIMABUKURO, M., GONÇALVES, S. and IMAI, N. Estimating the CDOM absorption coefficient in tropical inland waters using OLI/ Landsat-8 images. Remote Sensing Letters, 2016a, 7(7), 661-670. http://dx.doi.org/10.1080/215070 4X.2016.1177242.

ALCÂNTARA, E., WATANABE, F., RODRIGUES, T. and BERNARDO, N. An investigation into the phytoplankton package effect on the chlorophyll-a specific absorption coefficient in Barra Bonita reservoir, Brazil. Remote Sensing Letters, 2016b, 7(8), 761-770. http://dx.doi.org/10.1080/215070 4X.2016.1185189.

AMERICAN PUBLIC HEALTH ASSOCIATION - APHA. American Water Works Association AWWA. Water Environmental Federation - WEF. Standard methods for the examination of water and wastewater. Washington: APHA, AWWA \& WEF, 2005.

BABIN, M., STRAMSKI, D., FERRARI, G.M., CLAUSTRE, H., BRICAUD, A., OBOLENSKY, G. and HOEPFFNER, N. Variations in the light absorption coefficients of phytoplankton, nonalgal particles, and dissolved organic matter in coastal waters around Europe. Journal of Geophysical Research, 2003, 108(C7), 3211. http://dx.doi. org/10.1029/2001JC000882. 
BRICAUD, A. and STRAMSKI, D. Spectral absorption coefficients of living phytoplankton and nonalgal biogenous matter: a comparison between the Peru upwelling area and the Sargasso Sea. Limnology and Oceanography, 1990, 35(3), 562-582. http://dx.doi. org/10.4319/lo.1990.35.3.0562.

BRICAUD, A., BABIN, M., MOREL, A. and CLAUSTRE, H. Variability in the chlorophyllspecific absorption coefficients of natural phytoplankton: analysis and parametrization. Journal of Geophysical Research, 1995, 100(C7), 1332113332. http://dx.doi.org/10.1029/95JC00463.

CALIJURI, M.C. and SANTOS, A.C.A. Short-term changes in the Barra Bonita reservoir (São Paulo, Brazil) emphasis on the phytoplankton communities. Hydrobiologia, 1996, 330(3), 163-175. http://dx.doi. org/10.1007/BF00024205.

CALIJURI, M.C., SANTOS, A.C.A. and JATI, S. Temporal changes in the phytoplankton community structure in a tropical and eutrophic reservoir (Barra Bonita, SP - Brazil). Journal of Plankton Research, 2002, 24(7), 617-634. http://dx.doi.org/10.1093/ plankt/24.7.617.

CAMPBELL, G., PHINN, S.R. and DANIEL, P. The specific inherent optical properties of three subtropical and tropical water reservoirs in Queensland, Australia. Hydrobiologia, 2011, 658(1), 233-252. http://dx.doi.org/10.1007/s10750-010-0476-4.

CIOTTI, A.M., LEWIS, M.R. and CULLEN, J.J. Assessment of the relationships between dominant cell size in natural phytoplankton communities and the spectral shape of the absorption coefficient. Limnology and Oceanography, 2002, 47(2), 404-417. http://dx.doi.org/10.4319/lo.2002.47.2.0404.

CLEVELAND, J.S. and WEIDEMANN, A.D. Quantifying absorption by aquatic particles: a multiple scattering correction for glass-filber filters. Limnology and Oceanography, 1993, 38(6), 13211327. http://dx.doi.org/10.4319/lo.1993.38.6.1321.

CULlEN, J.J., CIOTTI, A.M., DAVIS, R.F. and LEWIS, M.R. Optical detection and assessment of algal blooms. Limnology and Oceanography, 1997, 45(5 part 2), 1223-1239. http://dx.doi.org/10.4319/ lo.1997.42.5_part_2.1223.

CURTARELli, M.P., OGASHAWARA, I., ALCÂNTARA, E. and STECH, J.L. Coupling remote sensing bio-optical and three-dimensional hydrodynamic modeling to study the phytoplankton dynamics in a tropical hydroelectric reservoir. Remote Sensing of Environment, 2015, 157, 185-198. http:// dx.doi.org/10.1016/j.rse.2014.06.013.

DELLAMANO-OLIVEIRA, M.J., VIEIRA, A.A.H., ROCHA, O., COLOMBO, V. and SANT'ANNA, C.L. Phytoplankton taxonomic composition and temporal changes in a tropical reservoir. Fundamental and Applied Limnology; Official Journal of the International Association of Theoretical and Applied
Limnology, 2008, 171(1), 27-38. http://dx.doi. org/10.1127/1863-9135/2008/0171-0027.

DUYENS, L.N.M. The flattening of the absorption spectrum of suspensions, as compared to that of solutions. Biochimica et Biophysica Acta, 1956, 19(1), 1-12. PMid:13304065. http://dx.doi. org/10.1016/0006-3002(56)90380-8.

GOLTERMAN, H.L. Developments in water science 2: physiological limnology: an approach to the physiology of lake ecosystems. Amsterdam: Elsevier, 1975.

GORDON, H.R., BROWN, O.B., EVANS, R.H., BROWN, J.W., SMITH, R.C., BAKER, K.S. and CLARK, D.K. A semianalytical radiance model of ocean color. Journal of Geophysical Research, 1988, 93(D9), 10909-10924. http://dx.doi.org/10.1029/ JD093iD09p10909.

LE, G., LI, Y., ZHA, Y. and SUN, D. Specific absorption coefficient and the phytoplankton package effect in Lake Taihu, China. Hydrobiologia, 2009, 619(1), 2737. http://dx.doi.org/10.1007/s10750-008-9579-6.

LOHRENZ, S.E., WEIZMANN, A.D. and TUEL, M. Phytoplankton spectral absorption as influenced by community size structure and pigment composition. Journal of Plankton Research, 2003, 25(1), 35-61. http://dx.doi.org/10.1093/plankt/25.1.35.

MATSUMURA-TUNDISI, T. and TUNDISI, J.G. Plankton richness in a eutrophic reservoir (Barra Bonita reservoir, SP, Brazil). Hydrobiologia, 2005, 542(1), 367-378. http://dx.doi.org/10.1007/s10750004-9461-0.

MISHRA, S. and MISHRA, D.R. Normalized difference chlorophyll index: a novel model for remote estimation of chlorophyll-a concentration in turbid productive waters. Remote Sensing of Environment, 2012, 117, 394-406. http://dx.doi.org/10.1016/j. rse.2011.10.016.

MOBLEY, C.D. Light and water: radiative transfer in natural water. San Diego: Academic Press, 1994.

MOREL, A. and PRIEUR, L. Analysis of variations in ocean color. Limnology and Oceanography, 1977, 22(4), 709-722. http://dx.doi.org/10.4319/ lo.1977.22.4.0709.

PAAVEL, B., KANGRO, K., ARST, H., REINART, A., KUTSER, T. and NÓGES, T. Parameterization of chlorophyll-specific phytoplankton absorption coefficient for productive lake waters. Journal of Limnology, 2016, 75(3), 423-438.

RICHARDSON, L.L. Remote sensing of algal bloom dynamics: a new research fuses remote sensing of aquatic ecosystems with algal accessory pigment analysis. Bioscience, 1996, 46(7), 492-501. http:// dx.doi.org/10.2307/1312927.

RIDDICK, C.A.L., HUNTER, P.D., TYLER, A.N., MARTINEZ-VICENTE, V., HORVÁTH, H., KOVÁCS, A.W., VÖRÖS, L., PRESTON, T. and PRÉSING, M. Spatial variability of absorption 
coefficients over a biogeochemical gradient in a large and optically complex shallow lake. Journal of Geophysical Research: Oceans, 2015, 120(10), 7040-7066.

RODRIGUES, T.W.P., GUIMARÁES, U.S., ROTTA, L.H.S., WATANABE, F.S.Y., ALCÂNTARA, E.H. and IMAI, N.N. Delineamento amostral em reservatórios utilizando imagens Landsat-8/OLI: um estudo de caso no reservatório de Nova Avanhandava (Estado de São Paulo, Brasil). Boletim de Ciências Geodésicas, 2016, 22(2), 303-323. http://dx.doi. org/10.1590/S1982-21702016000200017.

RUIZ-VERDÚ, A., SIMIS, S.G.H., HOYOS, C., GONS, H.J. and PEÑA-MARTÍNEZ, R. An evaluation of algorithms for the remote sensing of cyanobacterial biomass. Remote Sensing of Environment, 2008, 112(11), 3996-4008. http:// dx.doi.org/10.1016/j.rse.2007.11.019.

SCHALLES, J.F. and YACOBI, Y.Z. Remote detection and seasonal patterns of phycocyanin, carotenoid and chlorophyll pigments in eutrophic waters. Archiv fur Hydrobiologe Special Issues Advances in Limnology, 2000, 55, 153-168.

SIMIS, S.G.H., PETERS, S.W.M. and GONS, H.J. Remote sensing of the cyanobacteria pigment phycocyanin in turbid inland water. Limnology and Oceanography, 2005, 50(1), 237-245. http://dx.doi. org/10.4319/lo.2005.50.1.0237.

SMITH, W.S., ESPÍNDOLA, E.L.G. and ROCHA, O. Environmental gradient in reservoirs of the medium and low Tietê river: limnological differences through the habitat sequence. Acta Limnologica Brasiliensia, 2014, 26(1), 73-88. http://dx.doi.org/10.1590/ S2179-975X2014000100009.

STUMPF, R.P., DAVIS, T.W., WYNNE, T.T., GRAHAM, J.L., LOFTIN, K.A., JOHENGEN, T.H., GOSSIAUX, D., PALLADINO, D. and BURTNER, A. Challenges for mapping cyanotoxin patterns from remote sensing of cyanobacteria. Harmful Algae, 2016, 54, 160-173. PMid:28073474. http://dx.doi.org/10.1016/j.hal.2016.01.005.

TASSAN, S. and FERRARI, G. An alternative approach to absorption measurements of aquatic particles retained on filters. Limnology and Oceanography, 1995, 40(8), 1358-1368. http://dx.doi.org/10.4319/ lo.1995.40.8.1358.

TASSAN, S. and FERRARI, G.M. Measurement of light absorption by aquatic particles retained on filters: determination of the optical path length amplification by 'transmittance-reflectance' method. Journal of Plankton Research, 1998, 20(9), 1699. 1709. http://dx.doi.org/10.1093/plankt/20.9.1699.

TASSAN, S. and FERRARI, G.M. A sensitivity analysis of the 'transmittance-reflectance' method for measuring light absorption by aquatic particles. Journal of Plankton Research, 2002, 24(8), 757-774. http://dx.doi.org/10.1093/plankt/24.8.757.

TUNDISI, J.G., MATSUMURA-TUNDISI, T., PEREIRA, K.C., LUZIA, A.P., PASSERINI, M.D., CHIBA, W.A., MORAIS, M.A. and SEBASTIEN, N.Y. Cold fronts and reservoir limnology: an integrated approach towards the ecological dynamics of freshwater ecosystems. Brazilian Journal of Biology = Revista Brasileira de Biologia, 2010, 70(3, Suppl), 815-824. PMid:21085786. http://dx.doi. org/10.1590/S1519-69842010000400012.

WATANABE, F.S.Y., ALCÂNTARA, E., RODRIGUES, T.W.P., IMAI, N.N., BARBOSA, C.C.F. and ROTTA, L.H.S. Estimation of chlorophyll-a concentration and the trophic state of the Barra Bonita hydroelectric reservoir using OLI/Landsat-8 images. International Journal of Environmental Research and Public Health, 2015, 12(9), 10391 10417. PMid:26322489. http://dx.doi.org/10.3390/ ijerph120910391.

WATANABE, F., MISHRA, D.R., ASTUTI, I., RODRIGUES, T., ALCÂNTARA, E., IMAI, N.N. and BARBOSA, C. Parametrization and calibration of a quasi-analytical algorithm for tropical eutrophic waters. ISPRS Journal of Photogrammetry and Remote Sensing, 2016, 121, 28-47. http://dx.doi. org/10.1016/j.isprsjprs.2016.08.009.

Received: 19 January 2017 Accepted: 21 August 2017 